\title{
Neoliberalism Writ Large and Small
}

\author{
By Laura Jordan (Ludwig Maximilian University of Munich)
}

\section{Abstract}

General Motors restructured its worldwide operations in the 1980s to maximally exploit cheap labour markets around the world, and this had devastating results for local economies in many places, including Flint, Michigan (US). While this restructuring did not save General Motors from eventual bankruptcy, the severe economic and social problems engendered by factory closures in Flint put the city's local elites in a difficult position. Not only was their future prosperity no longer assured, but their exclusive status as elites became tarnished by the city's fall into disrepute. This article describes how local Flint elites who did not benefit from the large-scale neoliberal transformation of deindustrialisation have themselves resorted to neoliberal practices on a small scale to preserve their elite position. They have done this by mobilising personal ties to obtain public and non-profit financing for their own for-profit business projects in the city's downtown. Notwithstanding some contestation by area residents, these projects have been bolstered by hegemonic discourses portraying them as public works. 


\section{Introduction}

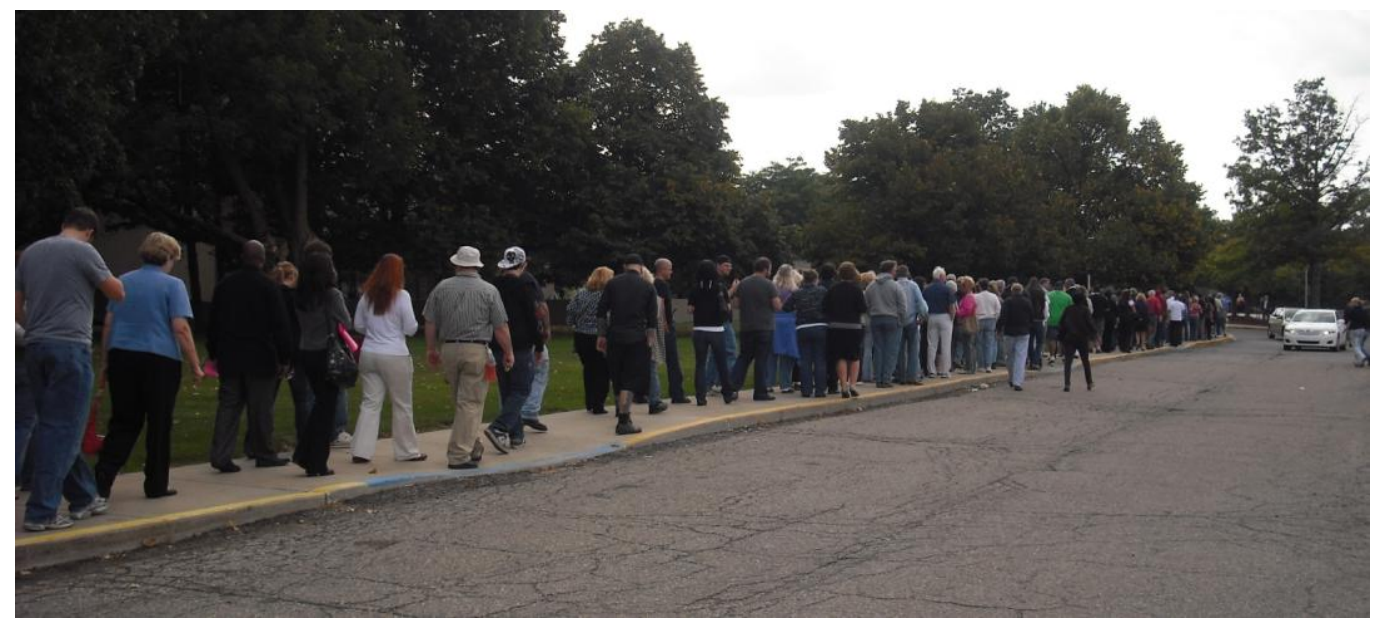

Figure 1: The queue of Flint area residents waiting to see Capitalism, A Love Story.

Photo by Laura Jordan

Almost 20 years to the day after the release of Michael Moore's (1989) documentary Roger \& Me - the film that first brought the devastation wrought by General Motors' (GM's) withdrawal from Flint into the international spotlight - Moore returned to Flint to host a free public premiere of his latest film, Capitalism, A Love Story (2009). Together with friends and family, I joined the queue of nearly 2,000 area residents from a variety of backgrounds who converged upon the city auditorium to see the local celebrity's most recent opus. As footage rolled onscreen, Moore's voice narrated the path of 'creative destruction' (Marx 1993 [1857]: 750; Schumpeter 1976 [1942]: 83; Harvey 2011: 215) that reforms initiated in the 1980s had inflicted on towns like Flint all across the US:

What Reagan presided over was the wholesale dismantling of our industrial infrastructure. This was not done to save money and remain competitive, as companies back then were already posting record earnings in the billions; no, it was done for short-term profits, and to 
destroy the unions. Millions of people were thrown out of work, and the remaining workers were told to work twice as hard. But wages for working people remained frozen. The richest Americans had their top income tax rate cut in half. Instead of being paid a decent wage, we were encouraged to live on borrowed money, until our household debt was nearly one hundred percent of the GDP. There was an explosion of personal bankruptcies. We found it necessary to lock up millions of our citizens. Sales of anti-depressants skyrocketed, while pharmaceutical and health insurance companies' greed pushed the cost of health care up and up. All of this was great news for the stock market and America's CEOs.

During the end of the Reagan years, I made my first movie about what had happened to the country, and specifically, to my hometown of Flint, Michigan, the birthplace of General Motors. GM was posting profits of over 4 billion dollars, while at the same time eliminating tens of thousands of jobs. I went to see GM's chief lobbyist in Flint, Mr. Tom Kay, to ask him why this was happening [segues to 1989 interview with Kay]:

Tom Kay: General Motors wouldn't be doing anybody any service if it goes bankrupt. It has to do what it has to do in order to stay competitive in today's economic climate.

Michael Moore: Even if it means eliminating 18,000 jobs?

Tom Kay: Even if it means eliminating 20,000 jobs.

Michael Moore: Or 30,000?

Tom Kay: Whatever.

Michael Moore: How about all the jobs here in Flint?

Tom Kay: It could feasibly happen. 
[Voiceover resumes:] And it did. Nearly all the jobs were eliminated, and [in 2009] GM went bankrupt. Perhaps more distressing was the fact that the rest of America was now starting to resemble Flint, Michigan (Moore 2009: 21:00-24:00).

At least one viewer walked out of the screening in disgust; he happened to be a resident of one of Flint's wealthiest suburbs (Longley 2009). Yet, my observation of the crowd confirmed media reports that Moore's analysis visibly hit a nerve among a majority of those present (ibid.). As the projector rolled scenes of worker-owned cooperatives, evicted tenants, and unsavoury connections between US banking interests and government officials, the air inside the auditorium became electric with the audience's emotional responses to the film's critiques of growing inequality in wealth and power in the US - belly laughs, tears, indignant grunts at the corrupt, and cheers and rounds of applause for those who 'spoke truth to power' (see Ingle 1998). While discussing the film with friends over dinner afterwards, my companions were similarly moved by Moore's analysis.

The particularly large and important bundle of macro-processes Moore described in his voiceover has become known to observers in the social sciences as 'neoliberalism' (see for instance Morgen 2001; Jessop 2002; Peck and Tickell 2002; Hairong 2003; Duménil and Lévy 2004; Greenhouse 2005; Saad Filho and Johnston 2005; Ong 2006; Newman et al. 2007; Read 2009; Wacquant 2012). As Maskovsky (2001: 15) and Kingfisher (2008: 1) point out, neoliberalism is not 'a thing that acts in the world,' but rather a process. There are at least two important ways in which neoliberal processes have, in general, been observed to affect ethnographic subjects' lived experiences. The first of these is ideological, and includes elements such as the influence of the Chicago School's theologisation of 'the market' (Harrison 2005), the conceptual remaking of personhood in the image of the individual (Gledhill 2004), and the broadening of the scope of what may be treated as private commodities (Lander 2001). 
Yet neoliberalisation is not merely limited to the realm of ideas, for ideologies have the power to shape discourses, perceptions, and actions (Althusser 2008 [1971]). Furthermore, it is precisely because attempts have been made to remake social relations in a neoliberal image via policy reforms and austerity-minded 'structural adjustment' programmes that we may speak not just of neoliberal doctrines, but also of neoliberal practices. And indeed, a multitude of ethnographic studies have documented the ways in which a combination of neoliberal ideologies and reforms have impacted non-elites (Comaroff and Comaroff 2001; Gledhill 2004). These impactful ideologies and reforms have included de-funding public services (Glick Schiller 2011), privatising public assets (Schwegler 2008), commodifying the environment (Aiyer 2007), weakening labour protections (Molé 2010), regressively redistributing wealth and power 'upwards' (Goode and Maskovsky 2001), imposing surveillance and 'audit culture' (Shore and Wright 1999), criminalising the poor (Wacquant 2009; Bourgois 2011), marginalising non-elites from decision-making processes (Brown 2005), and excluding them from strategically important spaces (Babb 1999; Butler 2003). As will become apparent in this article, many of these processes have been deployed on both large and small scales to negatively affect working-class people in Flint, where I conducted research in the late 2000s.

One of the key features of neoliberalism is the discrepancy between neoliberal theory and neoliberal practice. Counter to the democratic theories of 'trickle-down' economics and individual empowerment that are often used to justify neoliberal projects, numerous authors (see for example Hayek 2007 [1944]; Friedman 1962; Hayek 1978; Friedman and Friedman 1990 [1979]; Karjanen 2010; Duménil and Lévy 2001, 2004); Harvey 2005; and more recently Wacquant 2012) have argued convincingly that in practice, these projects tend to benefit economic elites to the detriment of non-elites. The findings of the ethnographies mentioned in the previous paragraph would seem to support this characterisation of neoliberalism, and I would agree that it is on the whole true. At the same time, this characterisation of neoliberalism also obscures the degree to which the category of 'elites' itself may be segmented. In this article, I wish to join 
Gledhill (2003) in drawing attention to the fact that the same neoliberal process can affect different groups of elites in different ways.

In the pages that follow, I will first give a general overview of my research context and methodology. Then I will describe two related neoliberal processes that have both funnelled resources away from Flint's working class residents, concentrating them instead in the hands of different groups of elites. The first of these processes, deindustrialisation, was engineered by and benefitted GM's upper management, and disadvantaged all groups in Flint - from the working class to local elites - albeit in different ways. The second process, downtown redevelopment, emerged as local elites' strategy to restore their own capital accumulation and prestige formerly damaged by deindustrialisation - again, at the expense of the local working class.

In the process of making this argument, I hope to nuance Duménil and Lévy’s (2001; 2004), Harvey's (2005), and Wacquant's (2012) assertions of the relationship between elites and non-elites under neoliberalisation by making two observations. First, all neoliberal processes do not necessarily benefit all elite groups uniformly. Second, just as 'the neoliberal period' is generally accepted to have been transnational economic elites' response to the large-scale crisis of capital that emerged in the 1970s, so too have smaller-scale ('local') elites, themselves disadvantaged by these large-scale neoliberal processes, responded to the resulting local crises of capital with neoliberal strategies of their own. As different groups of elites respond to crises on various scales with cascading levels of neoliberal reforms, the working class has suffered from - and often also struggled against - manifold processes of upwardly-trickling resources and de facto exclusion from official decision-making processes. These have happened both through public and corporate disinvestment in 'old' industrial communities and neighbourhoods (see Bluestone 1982), and through a diversion of public and charitable resources away from public services and grassroots initiatives, toward the for-profit business ventures of local elites. 


\section{Context and Methodology}

My knowledge of the phenomena described in this article derives from a variety of sources. First, Flint is my hometown, and my familiarity with events and actors in Flint owes a great debt to the fact that I have grown up immersed in local history, politics, and culture. My family continues to reside in Flint, and their debates about local politics have kept me abreast of the latest developments.

The data presented in this article was collected during a 12-month ethnographic and interview-based doctoral field research project in Flint during 2009-2010. The main focus of this fieldwork was actually different from the one in this article, centring instead on a cohort of local retail workers and their responses to austerity measures enacted at their workplace. The material on local elites presented here was originally gathered as background material on the socio-economic context that shaped these workers' life possibilities. It was only later during the data analysis process that this material emerged as interesting in its own right.

The material in question derives from both primary and secondary sources. It does not draw on interviews with the elites themselves. Instead, consistent with this article's focus on the material relations and public discourses surrounding public events in Flint, I assembled a collection of publicly-disseminated documents relating to these actors' downtown development projects - most of which happen to give voice to these actors' public framings of their activities. Many of these sources are articles published in The Flint Journal, the local newspaper, between 2007 and 2013. Other sources include press releases published by the individuals and organisations involved in these projects, and the web pages that they maintain. This article's argument draws extensively from these materials, while benefitting from the insights provided by my ethnographic research in the area. During my fieldwork, I attended community workshops and had numerous conversations with local actors with personal experiences with local elites and their development projects. The insights I gained from these encounters were documented in a field diary I maintained throughout the research period. Furthermore, 
many of the 57 retail workers and union officials whom I interviewed primarily about their workplace experiences also shared with me their memories and perspectives on Flint's deindustrialisation and downtown development projects.

Unlike journalism, which calls for anonymity to be used sparingly and for sources to be identified 'whenever feasible' (Society of Professional Journalists 1996), ethical standards in anthropology call for subjects to be anonymised by default (American Anthropological Association 1998; Association of Social Anthropologists 2011). Although some argue this guideline may protect anthropologists' claims from scrutiny just as much as it protects subjects from unwanted attention (May 2010), it remains the professional standard. It could be further argued that pseudonyms can serve a legitimate purpose in protecting anthropologists who write about elite actors, especially when these actors may be capable of retaliation. In order to uphold my ethical obligation to avoid causing harm, I have attempted to disguise their identities by using pseudonyms, and by refraining from referencing published sources that reveal these actors' real names. However, local media coverage of these prominent actors' relationships to recent downtown development projects has converted these actors into public figures, meaning they may nonetheless be recognisable to readers who are intimately familiar with Flint's politics. This article's reliance on publicly available information therefore serves a double purpose: to present a faithful analysis of public life in Flint, and to preclude any possibility of libel.

\section{Neoliberalism Writ Large: GM's Retreat from Flint}

General Motors was founded in Flint in 1908. Although their corporate headquarters were moved to Detroit in the 1920s, automobile manufacturing continued to be the single most important source of jobs in Flint well into the 1990s (US Bureau of Labor Statistics 2012a; b). The corporation's leaders also continued to be actively involved in city planning and politics at least into the 1970s (Highsmith 2009). While as a group these corporate directors held significant influence in Flint, the most influential of them 
all was Alfred James ('AJ') Rich. Rich was the son of a New Jersey capitalist; he came to Flint to become a founding partner in GM, and continued to reside at his estate in Flint until his death in 1973. Rich sat on GM's board for 60 years, and also served three terms as Flint's mayor. Through his GM holdings, Rich accumulated an immense fortune, several billion dollars of which he transferred to the AJ Rich Foundation, a taxexempt charitable organisation he founded in 1926. More will be said later about the AJ Rich Foundation, as it came to occupy an especially powerful position in Flint in the wake of deindustrialisation.

GM's - and by extension Rich's - fortune was built on a variety of factors, including the company's unchecked exploitation of labour in the 1930s, which came to an end after the Flint Sit-Down Strike of 1936-1937. The strike won recognition of the United Autoworkers union (UAW) across North America, and played a pivotal role in establishing what is conventionally seen as a 'social contract,' 'class compromise,' or 'Keynesian compromise' between US capital and labour that lasted for about 30 years (Kraus 1985 [1947]; Fine 1965: 692; Bluestone and Harrison 1982:133; Wright 2000; Duménil and Lévy 2005: 9). ${ }^{1}$ This 'compromise' is generally held to have included a social welfare system, labour protections, 'middle class' wages and benefits for unionised workers, and a balance of power between union and corporate hierarchies (ibid.). ${ }^{2}$

\footnotetext{
${ }^{1}$ Nelson Lichtenstein (2000), however, contests the idea of a mid-century 'class compromise.' He argues that this concept is a construct of the 1970s, and errs in overgeneralising phenomena such as peaceful labour-capital relations and working-class prosperity that were in fact much more unevenly distributed than the construct implies.

${ }^{2}$ It should be noted that in the US, the term 'middle class' tends to be applied more broadly than it is in many other countries, to include not only the professional and managerial strata of society, but also many people who might be considered 'working class' in the UK and other countries.
} 

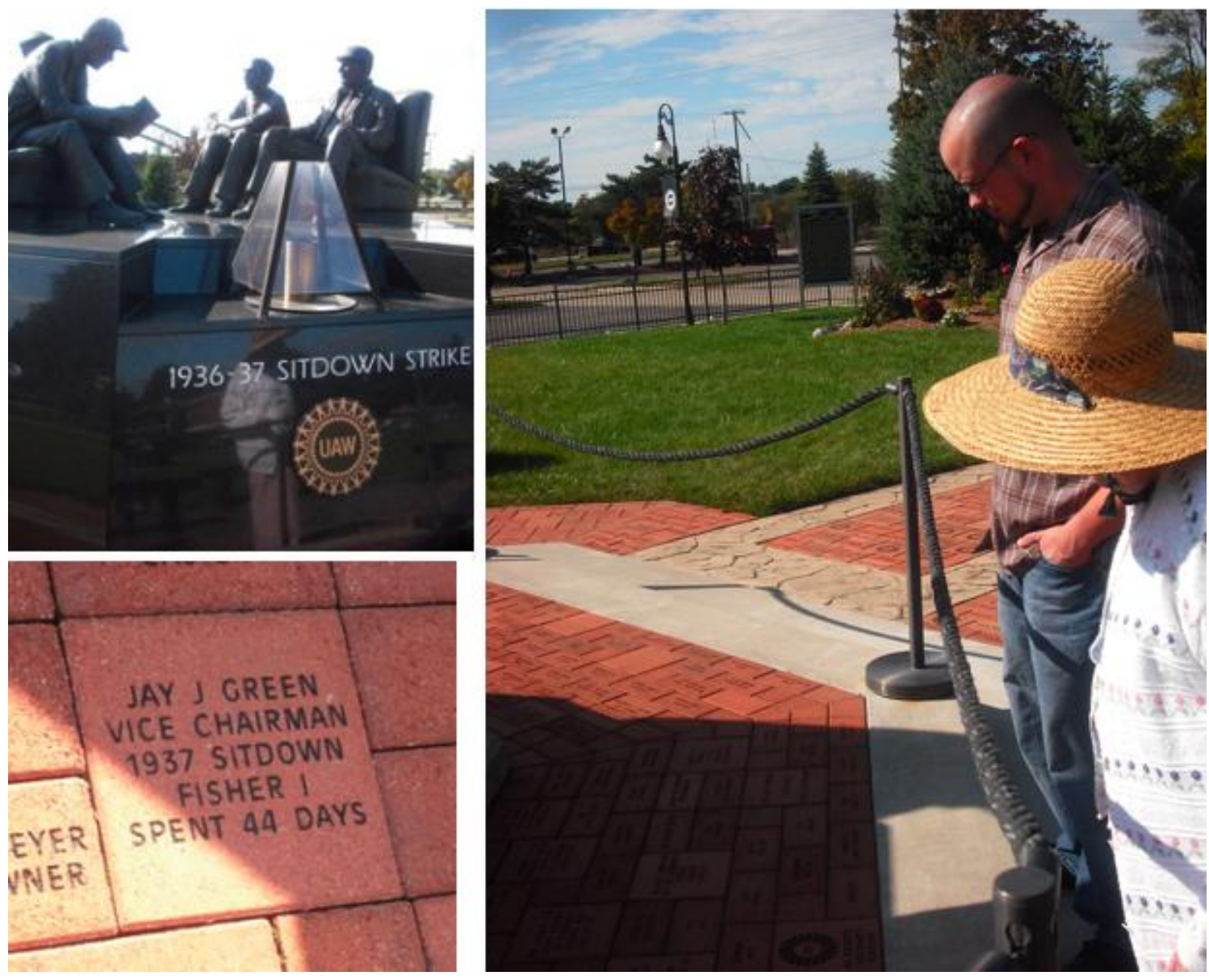

Figure 2: Sit-Down Strike Women's Brigade veteran Geraldine Blankinship and her great-nephew, himself a GM worker and activist, visit the brick dedicated to Blankinship's father at Sit-Downers Memorial Park in Flint. The park is near the factory (demolished in 1988) where the strike took place.

Photo by Laura Jordan.

Because GM was Flint's main employer, the recognition of the UAW was a watershed moment for local workers, ushering in a 'class compromise' in a very concrete way. Similarly to the situation Nash (1989: 125, 322) documented at General Electric, GM workers experienced the company's recognition of the UAW as a huge victory. Geraldine Blankinship, who had participated in the Sit-Down Strike's Women's Brigade and was 90 years old when I interviewed her, recalled that her father immediately noticed his bosses treating the workers with more respect, and that the standardisation and codification of worker rights and payscales measurably improved 
employment conditions. While the work itself continued to be hot, dirty, noisy, and dangerous, during the mid-twentieth century Flint's autoworkers were rewarded with high pay, strong job security, and reliable health and retirement benefits. These autoworkers' patronage supported a prosperous class of local elites whose businesses included auto dealerships, building contractors, and retail stores.

The 'golden age' lasted through 1966, when all the main indicators of GM's business posted record highs. These indicators included an all-time high stock price (see Figure 3), an all-time peak in the US market share (see Figure 4), record global revenues (see Figure 5), and an all-time peak in the stability of global profits (see Figure 6). Despite the fact that GM's global revenues continued a general upward trend until 2000, after 1967 all the other previously mentioned metrics began sliding downward, reaching worrisome lows in both 1971 and 1975. For the first time since the Great Depression, large-scale economic elites in the US (as elsewhere) had real reason to panic, and 'had to move decisively if they were to protect themselves from political and economic annihilation' (Harvey 2005: 15). As stock price and domestic market share continued to fall and global profitability became increasingly volatile, corporate leaders in Detroit grew nervous. They began charting a radical shift in the company's focus away from products and onto finances - a shift that was famously encapsulated in CEO Thomas Murphy's (1974-1980) statement that 'General Motors is not in the business of making cars. It is in the business of making money' (Kemper and Martin 2010: 235). At GM as elsewhere, the Board of Directors began offering company executives enormous financial incentives to put the new bottom-line oriented philosophy into practice:

As a consequence of Jensen and Meckling's 1976 agency theory paper, it became a standard practice to give executives, especially CEOs, large amounts of stock-based compensation. Before long, those who made the very most money were not people who built good companies, consumer franchises or workforces ... [but rather] those who could influence 
expectations and exploit vacillations in them (Kemper and Martin 2010:

235).

Thus-motivated GM executives came up with new strategies to satisfy the board's expectations (Levin 1993). One of these strategies was the financialisation of GM's business model (see Figure 7). Namely, GM entered the consumer finance market, selling insurance packages, banking services, mortgages, and even home equity loans to members of the public (Williams et al. 1986; Sherman 2009). By 1999, GM was deeply involved in the risky ('subprime') practice of selling mortgages to people who were unlikely to pay them back (Feldman 1999) - the same type of loans that were ultimately responsible for triggering the post-2007 global financial crisis, and also the bankruptcy of GM itself. ${ }^{3}$

\footnotetext{
${ }^{3}$ In 2006, while the US housing 'bubble' was still growing, GM spun off its subsidiary financial firm called GMAC - into a separate company, partly due to GMAC's poor credit rating (Isidore 2010). After the real estate bubble burst in 2007, GMAC was bailed out three times by the US government, receiving a total of $\$ 17.3$ billion in public money (Yousuf 2009). Ironically, the government awarded these loans to GMAC despite predicting that the firm would be unlikely to pay them back (Congressional Oversight Panel 2010). GM was bailed out with an additional $\$ 50$ billion, the fourth largest bankruptcy in US history (Isidore 2008; Goldman 2009; CNNMoney 2009). In 2010 - just one year after its bailout - the restructured GM re-entered the finance industry by buying yet another subprime lending company (Isidore 2010).
} 


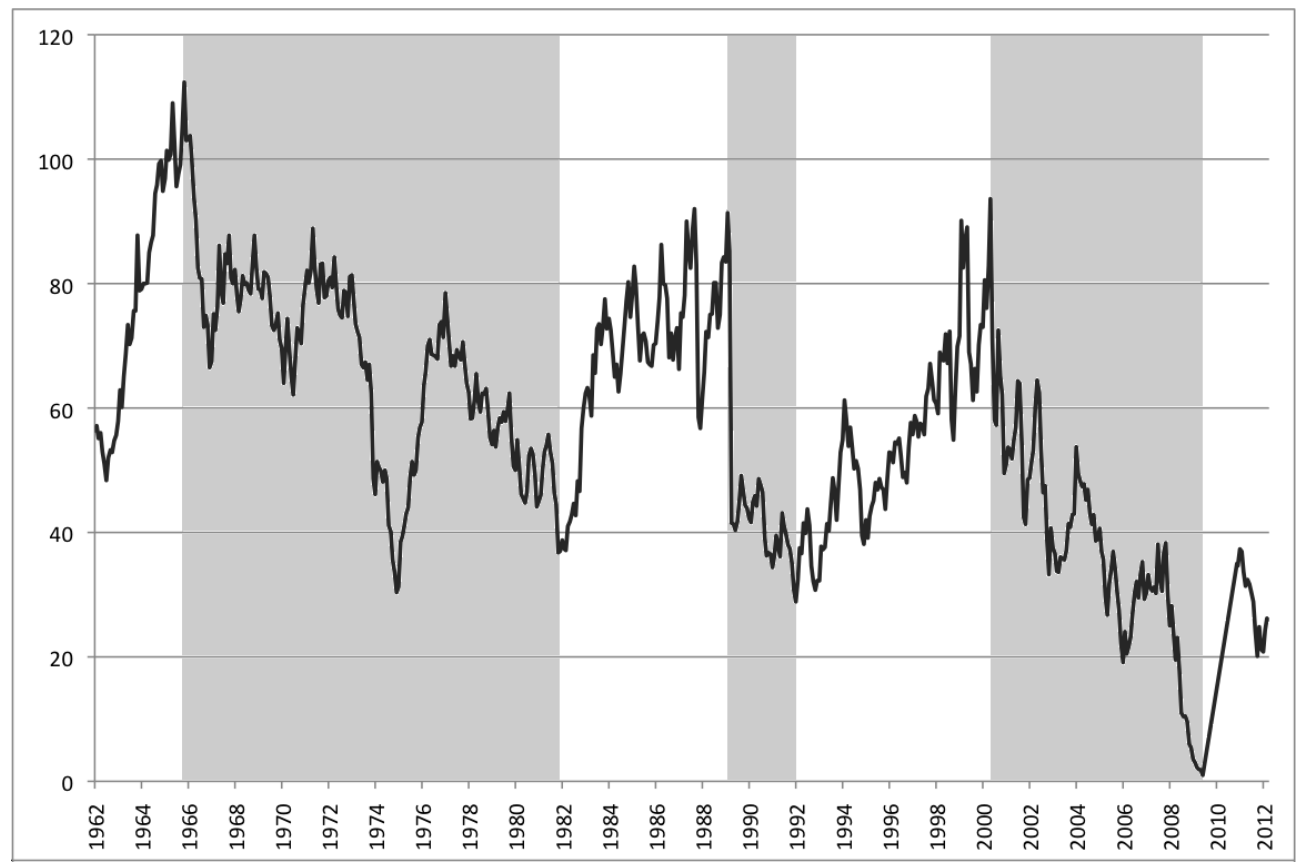

Figure 3: GM stock price in dollars, 1962-2012. Notice the all-time peak in 1966.

Periods of decline in investor confidence are shown in grey. Source: NYSE 2012.
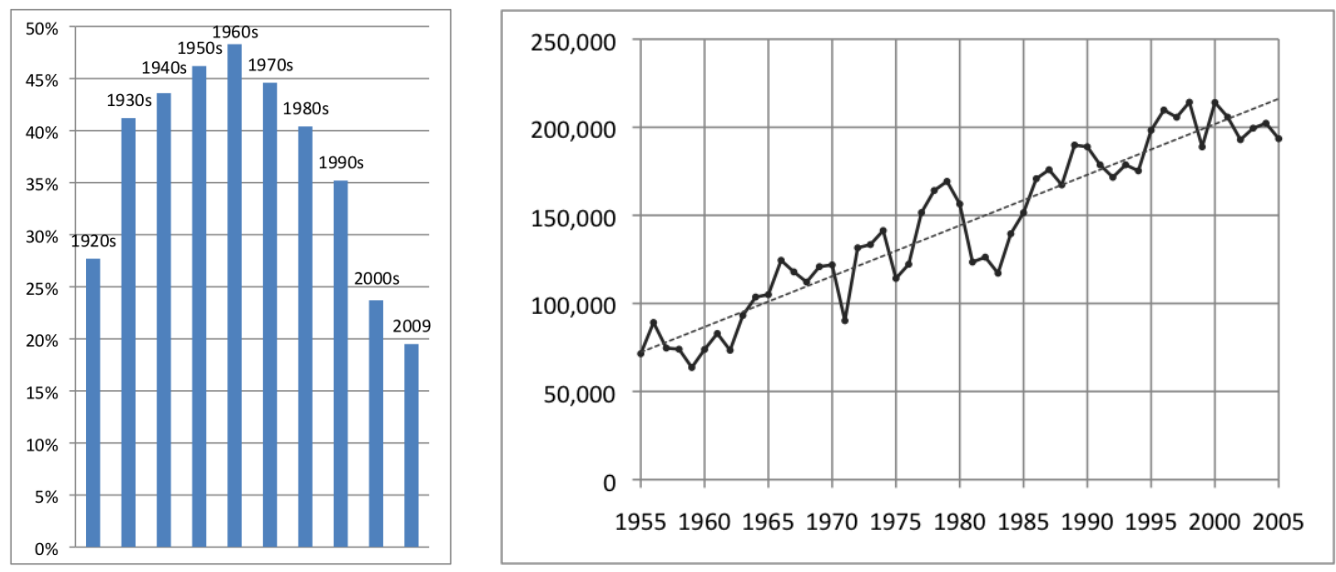

Figure 4 (left): GM's share of the US automobile market, from the 1920s to 2009, showing a peak in the 1960s. Source: Regassa and Ahmadian (2007).

Figure 5 (right): GM real global revenues, 1955-2005, shown in millions of (real) dollars. The dotted line shows a steady growth trend until 2000. Nevertheless, the periods of 1967-1971 and 1974-1975 saw declining revenues. Source: CNNMoney (2012). 


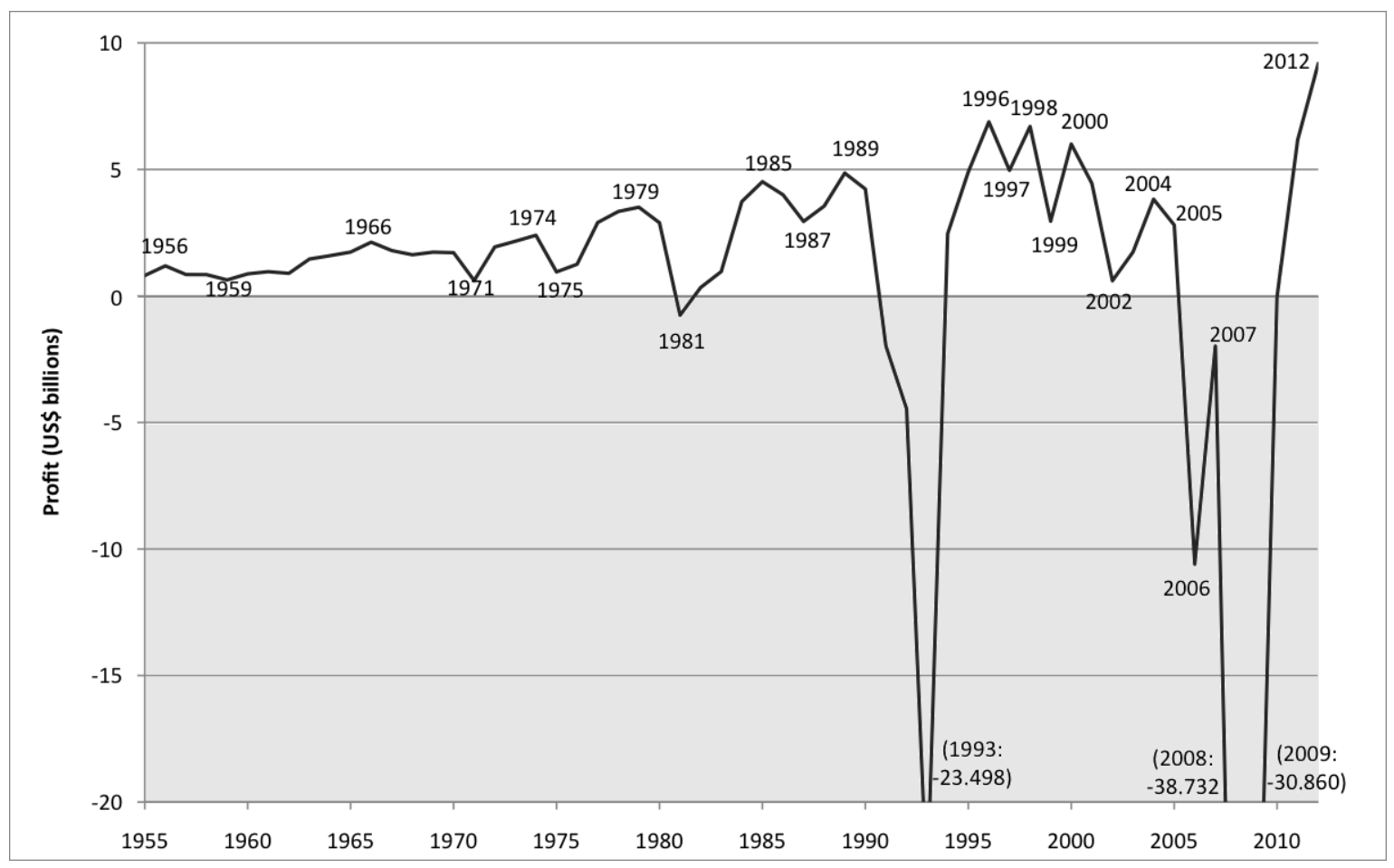

Figure 6: GM global profits, 1955-2012; stability of profits peaked in 1966. As a consequence of its own longstanding financial instability, exacerbated by the wider automotive industry crisis of 2008-2009, in 2009 GM filed for Chapter 11 bankruptcy and became reorganised under favourable terms. Source:

CNNMoney (2012). 


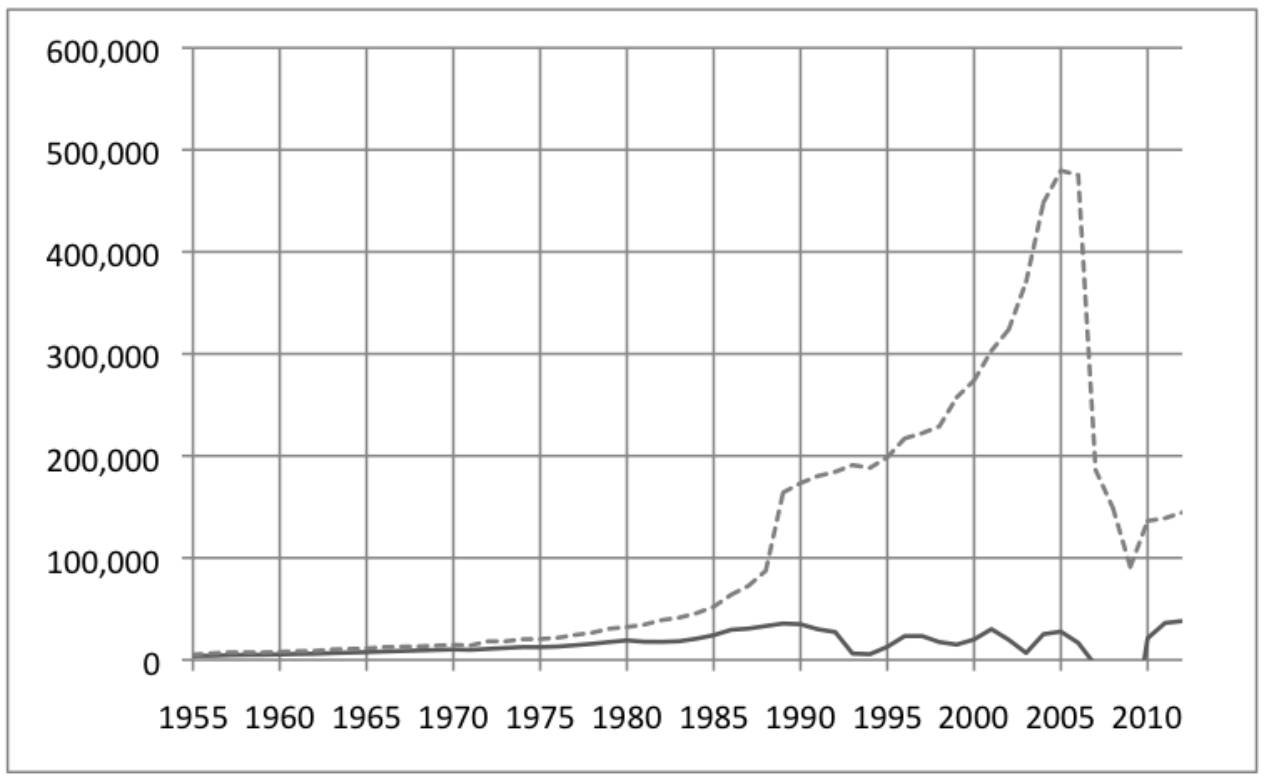

Figure 7: GM's assets, 1955-2012, shown in millions of US dollars; stockholder capital (solid line) is shown in relation to total assets (dotted line). The financialisation of GM's business is visible in the neoliberal-era mushrooming of GM's dependence on 'non-traditional' (non-stockholder-based) forms of capital.

Source: CNNMoney (2012).

Financialisation was not the only strategy that GM's top managers developed in order to reap the prodigal bonus incentives that the Board of Directors dangled before them; shutting down, idling, or cutting shifts at scores of factories in 'old' industrial cities like Flint also figured prominently in their strategies. They moved or outsourced production from places like Flint to lower-wage areas in the rural and southern US and around the world, sometimes with the assistance of government-negotiated free trade agreements (Taylor et al. 1990; Helper 1991; Fasenfest and Jacobs 2003: 158; Clemens 2011). ${ }^{4}$ The number of jobs in Flint's remaining factories was further reduced through automation. All told, between 1979 and 2010, Flint lost a staggering 87.5 percent of its manufacturing jobs (US Bureau of Labor Statistics 2012a; 2012b).

\footnotetext{
${ }^{4}$ For example, in 2009, Mexican autoworkers were paid less than one sixth of what their US counterparts were paid (US Bureau of Labor Statistics 2009a; 2009b).
} 
The imminent possibility of further factory closures put GM in a powerful position to demand concessions from the autoworkers' union (Lynd 1979; Collison and Gunnarsson 1985; Nash 1989). Consequently, autoworkers who kept their jobs took significant benefit cuts and a 33-percent wage reduction (Aronowitz 1992 [1973]). The introduction of wage tiers further degraded job conditions for incoming generations of workers (Richardson 2007; Fonger 2012), as did gruelling commutes:

The negotiated contracts provided high seniority workers with the ability to 'bump' into regional labor pools. This often meant that to maintain working in the auto industry, workers, particularly GM workers, found themselves working in plants hundreds of miles away from their homes, forcing them to commute to work. The 'gypsy auto worker phenomena' [sic] became an important issue within some facilities (Fasenfest and Jacobs 2003: 158).

According to Steve, a former 'gypsy autoworker' whom I interviewed in 2010, such a life was exhausting. In the winter he left home at 4 in the morning, arriving back at 8 or 9 at night. After accepting early retirement from GM, he got a minimum-wage job at a big box retail store. Steve's experience is not uncommon. Part-time, minimum-wage retail work - which normally does not offer health insurance - is now a far more significant source of jobs in the Flint area than manufacturing (US Bureau of Labor Statistics 2012b; 2012c).

For many in the local working class, however, deindustrialisation did not just mean a worse job - it meant no job at all. By the time of my fieldwork in 2009, Flint's jobless rate was 28.9 percent (Burden 2009). The concomitant poverty spawned social problems of every sort, including homelessness, substance abuse, low high-school graduation rates, and high crime rates (Miller 1999b; Federal Bureau of Investigation 2010). These social problems have been compounded by welfare cuts at the national 
and state levels, and by the chronic underfunding of local public services (Morgen and Maskovsky 2003; Fonger 2011; Longley 2011). Thus, during my fieldwork, uncollected garbage occasionally piled up along city kerbs, and the municipality's inability to afford necessary demolitions left vacant and condemned houses vulnerable to an unprecedented spate of arsons - pushing underfunded, understaffed fire and police departments to the limit (Walling 2012).

Although the local working class suffered the most serious consequences of GM's retreat from Flint, they were not the only ones to lose out under deindustrialisation. Local elites were negatively affected as well, in at least two ways. First, Flint's veritable economic depression dampened demand for the local businesses they owned thereby threatening their class status on a material level. Sociologist Steven Dandaneau (1996: 202) observed that local elites' statements about the downtown projects they developed in response to this crisis - which I will go on to discuss - revealed concern not with resolving the poverty-related social problems afflicting the working-class neighbourhoods in Flint, but rather with resolving their own dread of being shut out of the 'newly emergent global capitalist economy.'

In addition to these material concerns, deindustrialisation also threatened the exclusivity of these local elites' class status as Flint's reputation began crumbling in an embarrassingly public way. In the 1980s, Flint's social problems began receiving farreaching press coverage (see for example Zwerdling 1982), including a Money Magazine article declaring Flint 'the worst place to live' in the United States (Eisenberg and Englander 1987). The release of Moore's (1989) Roger \& Me brought the grim plight of Flint's masses even more squarely into the national and international spotlight (detailed in Moore 1992), converting Flint into an enduring icon of postindustrial urban decay. More recently, Flint has garnered national attention for having the highest violent crime rate in the country (Sauter et al. 2012). In response to this farreaching publicity, the local press has given ample voice to local elites' insistence that they are 'tired of the city's bad reputation,' and that this reputation needs to be 'shed' (Duggan 2008; Mostafavi 2008). 


\section{Neoliberalism Writ Small: Downtown Development Projects ${ }^{5}$}

Members of the local elite responded to these threats to their material and social status through two series of downtown development projects - one of which took place in the 1980s, and the other of which began in 2003 and continues into the present. I argue that through these projects, local elites have succeeded in improving their own situation both materially and socially, and that they have done this largely at the public's expense. In particular, they have persuaded public (government) and charitable (nonprofit) bodies to both funnel significant assets toward the ledgers of private businesses that they themselves own, and to assume the financial risk for these for-profit projects. All the while, the same elites have successfully constructed a heroic image of themselves in the media - one that portrays them not as profiteers, but rather as philanthropists investing their own money into projects benefiting the entire population of Flint.

\section{Projects and Capital Flows}

Beginning in 1969, an exodus of commercial activity into the suburban fringe rapidly emptied Flint's downtown of stores and shoppers (Flint Journal staff 1999; Machniak 1999). Ever since, the notion of 'saving' Flint's downtown has become a staple phrase in the vocabulary of local urban developers (Miller 1999a). Geographers Karan and Stapleton (1997: 207) note that local elites moved rapidly to organise institutional means for dominating the decision-making process about 'revitalising' the city centre:

\footnotetext{
${ }^{5}$ As discussed in the Methodology section, some of the material in this section is presented without specifying the source. Citations that revealed subjects' true identities were removed prior to publication in order to refrain from violating their anonymity. All uncited material derives from published sources that include Flint Journal articles published between 2007 and 2013, as well as press releases and web pages issued by the individuals and organisations involved in Flint's downtown development projects.
} 
In Flint economic elites quickly developed a private institution to focus (or centralize) the [planning] process, simultaneously legitimizing their interests and taking an early start in generating a policy response. The organization of interests seems to account for much in the Flint case, and the leading economic elites were well organized in the early 1970s when redevelopment plans were being formed. The president of the [Rich] Foundation and the Foundation's program officers, the mayor, and executives from local banks and from local General Motors facilities set the tone for 20 years of development in Flint.

These projects followed two incarnations. The first of these - which took place from the late-1970s to mid-1980s - was an attempt to convert Flint's downtown into a 'tourist mecca' centring on Autoworld, a theme park about the history of the automobile industry (Zwerdling 1982; Graham 1999). Local elites formed a lobbying organisation called the Flint Area Conference Inc. to campaign arduously for government financing of this first round of tourism projects (Graham 1999). While they argued that these projects would 'provide entry-level jobs in the midst of a severe local recession, bolster new downtown businesses ... and help diversify the county's tattered economy' (ibid.), as early as 1982, outside observers voiced scepticism about whether tourists could realistically be expected to flock to a deindustrialising wasteland to visit a theme park about the auto industry (Zwerdling 1982). Nevertheless, the Flint Area Conference Inc.'s lobbying efforts prevailed in securing over \$200 million in financing for the project (Lord and Price 1992: 160). However, the project failed shortly after completion, nearly bankrupting the city, write Lord and Price (ibid.):

Each of [these Autoworld-era] projects involved roughly the same group of institutional and individual actors. These projects were joint ventures of the city of Flint, the [AJ Rich] Foundation, the federal government ..., the 
state of Michigan, and a small group of private investors. The private investors were guaranteed a safe return on their capital since most of the money was borrowed through bonds backed by the city of Flint. In addition, private investors in Autoworld were eligible for tax credits ... When these tourist projects ultimately failed, the [AJ Rich] Foundation intervened and paid off the bonds to avert immediate bankruptcy for Flint government.

While bankruptcy was averted, these 1980s-era development projects nonetheless burdened the city government with substantial debt; twenty years on, Flint was still paying nearly $\$ 12,000$ per year to service the debt from these early projects (Dobrzeniecki 2006: 95).

These early downtown development projects share two main features with the projects taking place today. First, nearly all of these projects have generated income for the local (elite) owners of the contracting firms hired to design and build the structures involved (see for example Graham 1999). A second pattern to emerge is the same phenomenon noted by Lord and Price above - namely, the private 'investors' involved in these projects are shielded from financial risk by the government and the AJ Rich Foundation. During the Autoworld series of projects, these 'investors' were still national- and international-level firms. ${ }^{6}$ In the more recent round of development projects, however, the 'investors' involved have been local elites.

This more recent series of projects was launched in 2003, when Seth Burrell and Youssef Hamadeh - both of whom owned and managed local construction firms joined together with four other local elites to form a group collectively calling themselves the Upscale Group. Together, Upscale's members commissioned a thirty-

\footnotetext{
${ }^{6}$ These included Six Flags amusement parks, Hyatt hotels, and the more obscure CRI Group (based in Rockville, Maryland).
} 
page strategic report detailing their vision to turn Flint's downtown area into 'a source of pride for residents [that can] serve the needs of a prosperous and evolving neighborhood, city and metropolitan region.' This plan outlined a vision for a complete physical transformation of the downtown space over the next twenty years, during which time that space would be rebuilt to cater specifically to the area's most affluent residents - namely, its 'older [college] students, young professionals and entrepreneurs, singles, empty nesters, and couples without children' - a target audience an Upscale spokesperson referred to as "higher Genesee County." Although the report characterised Upscale's plan as a 'public-private partnership,' it concluded that Upscale itself was 'the logical organization to undertake th[e] weighty role' of acting as the single entity coordinating and overseeing the development of Flint's downtown. By contrast, the only role that the plan allocated to the government played was to finance these projects through grants and tax breaks, and for government employees working downtown to patronise the businesses that Upscale would set up there. Similarly, the only role that Upscale's plan envisioned for community residents was to spend time and money downtown, and to maintain a 'positive perception and attitude' toward the changes taking place. The plan did not indicate that dissent, public oversight, or the preferences of the city's low-income residents would be welcome or accommodated. Rather, it made oblique reference to the project's dependence upon the punitive force of the state to keep the poor in check (see Wacquant 2009) by stipulating that the 'enhanced safety and security' of the downtown area would be paramount to the project's success. In short, 'public-private partnership' meant that ownership, management, and profit would be private, while financing would be largely public.

How have these projects proceeded in practice? The Barista Building project illustrates the typical pattern of relationships involved. As with most of Upscale's projects, a central actor in the Barista project was Grosvenor Young. Young is AJ Rich's greatgrandson, and the son of the Rich Foundation's current President and Chairman of the

\footnotetext{
${ }^{7}$ Genesee County is a political and administrative unit within the state of Michigan. Flint is its county seat.
} 
Board. Young himself juggles simultaneous roles as Vice President of the Rich Foundation, Project Manager of the Upscale Group, and co-owner of the Burrell-Young construction firm. This triple role is facilitated by the fact that the Upscale Group and Burrell-Young Construction share an office suite within the AJ Rich Foundation Building. The Barista Building, for its part - located on the main street of Flint's downtown - was donated to one of Young's employers (the Upscale Group) by another of his employers (the AJ Rich Foundation). Young's wife's architectural firm was hired to design the renovation. Babcock Construction - of which Young's friend (and Upscale member) Seth Burrell was Vice President - was engaged to carry out the renovation. Once the work was finished, Upscale leased the renovated space to a deluxe restaurant-bar owned by the same Seth Burrell.

Similar relationships were involved in the Russell Building project, which sought to combine three adjacent buildings on Flint's main street into one. As usual, Grosvenor Young acted as Project Manager, and his wife's firm was awarded the architectural contract. Goldsmith Construction - owned by Upscale member Youssef Hamadeh was contracted to build it. As with other Upscale projects, the Upscale Group was ultimately responsible for only a fraction of the Russell Building project's total cost. The bulk of the project was capitalised through a combination of charitable and government funds. The charitable funds took the form of grants from the AJ Rich Foundation. Every year, the Rich Foundation awards tens of millions of dollars in grant money to organisations in the Flint area - and in 2006, a remarkable 15 percent of that money was awarded to Upscale's development projects.

The government funds, for their part, took several forms. The feasibility study for the Russell Building project was partly funded by 'very significant tax credits. ${ }^{8}$ The state

\footnotetext{
${ }^{8}$ In the US, tax credits (also called tax abatements) are fixed sums of money subtracted from the total amount of taxes that a business or individual owes the municipal, state, or federal government. Many tax credits are refundable, meaning that if the tax credit sum is larger than the amount of taxes that would normally be owed, the government must pay the business or individual the difference. Thus, if a business
} 
of Michigan contributed $\$ 1.1$ million in the form of tax credits, and the federal government contributed funds both through tax credits and stimulus money. The Russell Building project was able to further increase the amount of federal aid it was eligible for by dividing the project into separate components on paper. Partway through the construction of what was expected to be a \$13 million project, a wall in the Russell Building collapsed, increasing the total cost to $\$ 23$ million. The $\$ 10$ million difference was recouped through additional tax credits, and another $\$ 5.5$ million from the AJ Rich Foundation and a private insurance settlement.

Once these and other downtown projects were finished, Upscale retained ownership of the buildings to lease out both office space and luxury loft apartments - the latter at rates ranging from $\$ 1,000$ to $\$ 1,500$ per month. These rents were a source of revenue to Upscale's members that further complemented the contributions of government and non-profit actors. According to Grosvenor Young, only 75 percent of this rent money is needed to meet costs; the remainder is profit.

Another boon to Upscale came from a project that was completely funded and managed by the city. The Central Parking Structure project was a product of the Upscale group's lobbying efforts. However, it was not overseen by Upscale directly, but rather by a municipal government organ called the Downtown Development Authority (DDA). Although Upscale and the DDA are separate entities, at the time of writing one-third of the members of the DDA also sat on the board of Upscale Developments. The DDA is also subordinate to the Mayor and the City Council, ${ }^{9}$ both of which have been responsive to Upscale's lobbying efforts. In response to Grosvenor Young's assurance that Upscale's tenants urgently needed more parking, and that the proposed structure would quickly pay for itself, the City Council voted unanimously to approve $\$ 10$

that would normally pay $\$ 50,000$ in Michigan taxes receives a $\$ 1$ million refundable tax credit, then the state government is obligated to pay the business $\$ 950,000$.

9 The Mayor and the (unicameral) City Council are the two most powerful actors in Flint's city government. Their relationship is somewhat analogous to that of the President and Congress on the national scale. 
million in bonds to fund the project, thereby committing the city government to assume all the financial risk. Grosvenor Young's wife's firm was awarded the contract to design the structure, and construction began in 2008.

Shortly thereafter, the City Council proposed to additionally award special 'Renaissance Zone' tax breaks to three of Upscale's newly-completed buildings. However, to take effect they needed the Mayor's signature. Citing concerns that the proposed tax breaks would reduce the city government's revenue at a time when revenue was badly needed to pay back the loan for the Central Parking Structure, the Mayor refused to sign. Through a concerted lobbying effort, however, Upscale members persuaded the Mayor that the city's finances would 'be worked out,' and that failure to approve the tax breaks would place the downtown's future 'in jeopardy.' Consequently, the Mayor reversed his position, approving the tax breaks. This measure exempted Upscale from nearly 100 percent of state and local property taxes on these properties through to 2023, and similarly exempted the buildings' tenants from personal property taxes. ${ }^{10}$ In return, the representatives of the Upscale Group offered the Mayor their 'heartfelt thanks for [his] efforts.' The Central Parking Structure opened in 2009, and it soon became clear that the Mayor's initial misgivings about the tax breaks had been justified. Namely, in the first six months, the new parking deck drew less than 1 percent of expected traffic (and revenue) - leaving the city responsible for $\$ 10$ million in debt payments on a structure that had been built expressly to benefit downtown businesses and their owners. By 2012, the situation had improved slightly, although it was not certain that the increased revenue would be high enough to help relieve the public-debt burden associated with the project.

As may be recalled, in addition to the municipal debt and loss of tax revenue that accompanied this latest series of downtown development projects, the city government also continued to carry debt from the development projects of the 1980s. All of these

\footnotetext{
${ }^{10}$ For tax purposes, 'personal property' includes all possessions that are capable of being removed from a building without doing damage to the building itself (e.g. furniture, equipment, artwork, cars, etc.).
} 
development-related revenue losses and debts compounded with other problems pressing on the city's finances to the point where in 2010, the city government was operating at a \$15 million deficit. On the day of Flint's 2011 mayoral election, Michigan's Governor cited this deficit as grounds for stripping Flint's elected officials of authority and placing the city under the absolute control of an appointed Emergency Manager. This Emergency Manager soon drew public criticism for suspending City Council meetings, establishing six-figure salaries for himself and his appointees, unilaterally rewriting contracts with public-sector unions, and sharply increasing fees for residents to access water and other essential services. ${ }^{11}$

As might be expected in light of the above information, Flint's Emergency Manager has continued the elected city government's practice of dedicating assets to local elites' downtown development activities. One journalist reporting on this flow of resources suggested that it might have been partly attributable to longstanding ties between the Emergency Manager and a particular member of the Upscale group. Whatever the reason, in 2010 a court order forced the city to buy Flint's tallest building, the vacant and decrepit Flint Towers building, from its (non-Upscale) owner for a total of $\$ 9$ million. ${ }^{12}$ Later, in 2012, Flint's Emergency Manager sold the building to Upscale for $\$ 1$ without public notice. He also transferred $\$ 750,000$ in federal grant money to go towards Upscale's demolition of the building. Upscale approached the AJ Rich Foundation for additional grant money to finance the demolition, and declined to comment on any of these transactions to the press.

\footnotetext{
${ }^{11}$ All attempts to contest the imposition of Flint's Emergency Manager - including protests, acts of civil disobedience, lawsuits, and even a statewide plebiscite - have thus far been thwarted by police and/or state officials. Thirty-five days after a referendum of Michigan voters repealed the Governor's Emergency Manager law, the Governor signed a new Emergency Manager law into effect.

${ }^{12}$ Homeowners in the city were forced to pay an average of $\$ 150$ each in a special tax levied to cover the city's debt to acquire the property; no poverty exemptions were granted.
} 


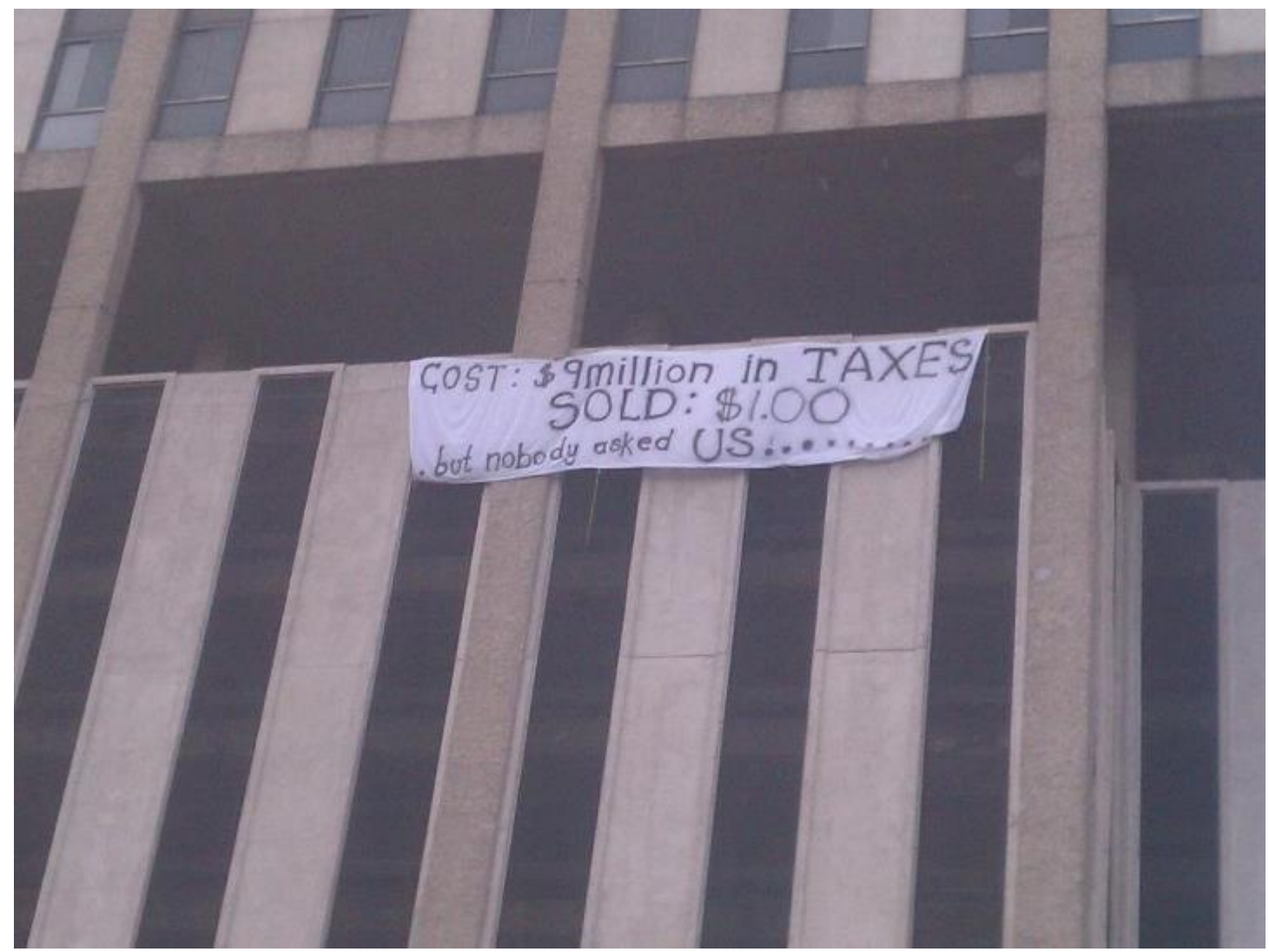

Figure 8: A banner hangs from the Flint Towers building protesting the terms of its sale to Upscale.

Photo courtesy of Brian Morrissey.

The Flint Towers sale agreement contained a clause seemingly unrelated to the building itself, barring the City of Flint from promoting the establishment of any other farmers' market besides the Flint City Market (which was owned by the city but managed by Upscale). ${ }^{13}$ Months later, Upscale unveiled a decision to dissolve the public market and shepherd vendors and patrons to a new, Upscale-owned market operating under the same name. The Flint Towers agreement, then, bound the city to protect Upscale's monopoly on the farmers' market once it was privatised. Public discourse about the privatisation has been stifled by the local press's failure to acknowledge this aspect of the new market. Instead, local media coverage has focused exclusively on the user-

13 In 2002, Flint's then-Emergency Manager transferred the market's management from the city government to Upscale after the city no longer had funds to run it. The city, however, retained ownership. 
friendliness of the market's new building (which Young's wife's architectural firm was hired to design). To create parking space for the new market, Upscale coveted a cityowned parking lot that generated revenue for the city and helped it pay off debt from the Central Parking Structure. The city sold this money-making lot to Upscale for twothirds of its appraised value, and then gave the proceeds of sale back to Upscale in exchange for title to a building whose value was decreasing.

The Michigan School for the Blind project provides a final example. Unlike the other projects, it is not technically in the city centre, but rather one mile west of downtown. In 2010, the state of Michigan sold the entire eighty-acre (thirty two hectare) campus of this state-wide school for children with special needs for \$1.3 million to Burrell-Young Construction - a firm that is co-owned by Grosvenor Young and Seth Burrell, and that also shares office space with Upscale. The sales agreement bound Burrell-Young to renovate the site, and bound the state to lease part of the property back from BurrellYoung for a period of twenty years, at an annual rent of \$2.6 million. The state agreed to these terms even though Burrell-Young anticipated the project would only cost $\$ 36$ million and acknowledged that they stood to profit from the venture. Despite this, Flint's City Council sought to further 'incentivise' the project by unanimously voting to tax the property at a significantly reduced rate for a period of twelve years. With City Council's blessing, the state also pledged an additional $\$ 5.6$ million for the project in the form of brownfield tax credits, although these credits were later rescinded. The school's Alumni Association waged a campaign opposing the project, alleging that it would '[not] take into account the needs of [the school]'s students, cost the state too much money and could drive the school out of operation.'

\section{Hegemonic and Critical Discourses}

Taken together, the flow of resources involved in these projects seems to follow a common pattern. In every instance, the city, state, and federal government, together with the AJ Rich Foundation, have assumed the bulk of the financial burden for these 
projects. According to the AJ Rich Foundation's 2008 Annual Report, about \$200 million in public and charitable (Foundation) funds were dedicated to Upscale's development projects between 2004-2008 alone, while the Upscale 'investors' contributed only $\$ 2.5$ million - about 1.2 percent of the total capital involved.

The information presented thus far seems to suggest that these projects have supported Upscale-affiliated elites' accumulation of wealth through a variety of means. These means include acquiring real estate for free or at bargain prices, capitalising on donated grant money and low- or zero-interest loans, awarding construction-related contracts to businesses that they or their family members own or manage, collecting premium rents from building tenants, collecting revenues from occupant-businesses that they or their family members own, and enjoying tax exemptions on these properties, rents, and revenues.

Upscale affiliates, AJ Rich Foundation spokespeople, and officials at various levels of the government have sought to legitimise these capital flows by asserting that the Upscale members are 'investors' in the community, and that their projects benefit the public more than they benefit the investors themselves. This framing has become hegemonic in local political discourse through repeated exposure in a variety of contexts, ranging from quotes in press reports to public speeches and presentations at City Council meetings.

Sometimes these statements are explicit. For example, in a public meeting, Upscale member Jerry Kaufer claimed that the Upscale have received little in the way of 'financial help.' He further rejected the suggestion that members of the Upscale Group might be profiting from downtown development projects, maintaining instead that: 'We started this as a social project, and despite what people say, there aren't financial benefits.' The newspaper article reporting the meeting brought Kaufer's claims to a larger audience by quoting him extensively. Reminiscent of the 1950s-era General Motors slogan that 'what was good for the country was good for General Motors and vice-versa' (Bose 2010: 41), government officials and Upscale spokespeople have 
argued that "when the downtown is alive and growing, Genesee County is alive and growing.' In a variety of formats, they have explicitly described the current round of downtown development projects as 'win-win for the community,' 'a good thing for the entire region,' 'a great moment for Flint and Genesee County,' an undertaking that it is 'putting back together our local economy' and 'sparking a new future for all of Genesee County.' More often, however, assertions about the projects' public value are made implicitly, through the speaker's (or writer's) choice of words. When examined closely, the adjectives and phrases most commonly employed in the press releases and newspaper reports about Upscale's projects appear to make five general claims about them.

The first of these claims asserts that Upscale investors are legitimate public leaders. Upscale members are described as 'a diverse group of community leaders,' 'business leaders' and 'investors that have strong ties to the community and own and manage some of the most respected businesses in Flint,' and 'downtown and economic development leaders' who are 'community-minded' and 'giving back to [the] community.' They are furthermore said to have 'accomplished' a great deal, and 'stepped up to meet [the] challenge.' The hegemonic status of this framing has been buttressed by the numerous awards that local and national organisations have bestowed upon members of the Upscale Group, partly in recognition of their putatively philanthropic role in downtown development projects. The spokesperson of one organisation honouring Jerry Kaufer likened Kaufer to Martin Luther King Jr., arguing that both men's actions were comparable 'in terms of doing something good for the community and bringing people together.'

The second of these implicit claims is that the projects themselves are positive. This is conveyed when they are described as 'great,' 'wonderful,' 'exciting,' 'cool,' 'appealing,' 'beautiful,' 'attractive,' 'stylish,' 'spectacular,' 'successful,' 'good news,' and an 'opportunity' inspiring observers to be 'optimistic' and full of 'hope.' The third is that these projects are an improvement over the past. They are portrayed as signs of 'growth' and 'progress,' as omens that the city is headed in a 'better' direction, and that 
'Flint is on the upswing.' The fourth assertion is that these projects are a manifestation of economic health. They are characterised as 'strong,' 'healthy,' 'thriving,' and 'vibrant' - full of 'vitality,' 'energy,' and 'momentum.' Finally, the fifth claim implicit in the language surrounding these projects is that they are a vehicle for the city's economic rebirth. They are described as driving a process of 'redevelopment,' 'revitalization,' 'revival,' 'regeneration,' 'rejuvenation,' 'resurgence,' 'rebounding,' 'bouncing back,' and 'transformation' - one that breathes 'new life' into the city.

Longings for a more 'appealing,' 'vibrant,' city were expressed not only by newspaper reporters and Upscale's press releases, but by a wide range of actors, including many of the retail workers whom I interviewed during my $\mathrm{PhD}$ research. The emotional tenor of these longings is perceptible in the following excerpt of an essay by Flint resident Jan Worth-Nelson (2013):

I want to think something different about this town. I want to feel something different about this town. Just like a lot of people, I get attached to places ... Time after time after time, things we thought we could count on, or things we'd become fond of, or things we simply liked - gone, gone, gone. And what have we learned from all this decimation? Well, let's just say we've got trust issues ... I just want something smart, for once ... I want somebody to do something right, something classy, something kind to the earth, something redemptive, damn it, something that addresses the turmoil and torment of our poor and dispossessed. I want someplace I can go without feeling lousy about Flint. I want someplace to hang out that makes me happy, that makes me healthy.

Upscale's projects make an appeal to some of these aspirations, but not all of them. Worth-Nelson expresses a desire for 'something that addresses the turmoil and torment of our poor and dispossessed.' Together with the lack of public input into the decision- 
making process, this is perhaps the point on which the Upscale Group's downtown development projects have been most sharply criticised. Local residents have spoken in public meetings and on local radio, held protests, engaged in acts of civil disobedience, and even sought positions on Upscale's Board of Directors to contest Upscale's virtual monopoly on local redevelopment resources. They assert that the public and charitable assets currently being funnelled towards Upscale's projects would be better invested in the urban neighbourhoods where the vast majority (98.1 percent) of the city's population lives, and where the need for resources of virtually every kind is the greatest (US Census Bureau 2000; 2010a; 2010b; 2010c; 2010d; 2010e; Sauter et al. 2012).

In general, Upscale's representatives and allies have called such criticisms 'frustrating,' arguing that 'negative thinking' and 'nay-saying' threaten to 'take us off track.' When pressed for particulars, Flint's Emergency Manager dismissed complaints about the lack of transparency surrounding his dealings with Upscale as 'conspiracy' theories. Similarly, at a community meeting, a state official defended the government's preferential treatment of Upscale's development projects by claiming that 'you can't serve all neighbourhoods equitably.' Areas that are already experiencing success and growth, he maintained, should rightfully receive public funds in preference to those that are 'too far south." 14

In harmony with this logic, the Upscale Group has maintained in words and deeds that they are only interested in the city centre, not in Flint's urban neighbourhoods something that they call 'commitment to the downtown area.' Yet this commitment muddles hegemonic claims that the development projects benefit the community as a whole. In a strange twist of logic, members of the Upscale Group have enjoined city residents to align their priorities with Upscale's. 'To sustain what's been accomplished,' contends Upscale member Jerry Kaufer, 'the community, the residents, have to want a vibrant downtown; they have to come down here and spend money.'

\footnotetext{
14 'Too far south:' an idiom implying that their conditions are so bad that they cannot be helped.
} 


\section{Conclusion}

In this article, I have argued that Flint's elites have responded to GM's large-scale neoliberal disinvestment in Flint (which harmed them as well) with smaller-scale neoliberal projects of their own. These actors mobilised personal networks to funnel public and charitable funds away from the city's low-income neighbourhoods toward spaces and for-profit businesses that both cater to the county's high-income residents, and financially benefit their own social networks. In the process, the local working class has suffered doubly: from deindustrialisation, and from public resources funnelled toward the accumulative projects of the local economic elite. In so doing, these development projects have perpetuated historical patterns of class-based inequality.

In making this observation, I am not suggesting that there is anything remarkable about the Upscale Group's (or General Motors') behaviour - nor am I suggesting that their behaviour is necessarily malevolently intended. They have styled themselves as philanthropists, and been received as philanthropists; they are doing exactly what their social circle considers to be 'the right thing,' and available evidence would furthermore seem to suggest that their actions enjoy economic rewards. In other words, their behaviour makes sense because the conventional wisdom and economic rules of the capitalist system encourage them to act this way.

The phenomenon of redirecting public and charitable resources toward for-profit business efforts is not particular to the neoliberal period. In 1906, a housepainter in England penned a semi-autobiographical novel describing similar patterns of social relations among his town's elites (Tressell 1914 [2012]). So these relations are not in and of themselves neoliberal. Their neoliberal aspect lies in their participation in a cascading series of reaction to the ideologically-legitimated post-1966 capital accumulation that has included the financialisation of the economy and the deindustrialisation (and redevelopment) of 'old' global manufacturing centres, as well as the establishment of new ones (see Nash 1995; Duménil and Lévy 2001; 2004; 
Harvey 2005). These relations thus become meaningful when understood both within the broader economic and ideological framework of the capitalist system, and in the historical context of Flint's experience of the neoliberal turn at the end of the twentieth century.

In this text, I hope to have illustrated that all neoliberal processes do not necessarily benefit all strata of elites uniformly. What benefitted GM's leaders did not benefit Flint's local elites. The latter reacted to their own losses under the local deindustrialisation crisis with downtown development projects. In both cases, however, elites successfully furthered their own interests in reaction to cascading crises, always at the expense of the working class - as in both scenarios, resources were transferred 'upward,' away from government and charitable bodies that were nominally purposed for the public good, and toward a small number of private hands. In both cases, this transfer was legitimated through public discourses arguing, in essence, that (to paraphrase previously-quoted GM lobbyist Tom Kay): '[Government] wouldn't be doing anybody any service if [elites] go bankrupt. It has to do what it has to do in order to [ensure that elites] stay competitive in today's economic climate' (Moore 2009: 23:00-23:30).

\section{About the Author}

Laura Jordan (now Laura Mebert) was born and raised in Flint. She received her $\mathrm{PhD}$ in Social Anthropology from the University of Manchester, and is preparing a book based on her thesis about Flint retail workers' responses to corporate restructuring. From Summer 2014 she will be an Assistant Professor of Social Science in the Department of Liberal Studies at Kettering University in Flint. 


\section{Acknowledgments}

The author gratefully acknowledges the support of a Social Anthropology $\mathrm{PhD}$ Studentship and an Overseas Research Studentship from the University of Manchester. This article has been several years in the making. A rudimentary version of this paper was presented at the 2010 'Temporal Relations and Change' conference at the University of Manchester, where participants' feedback proved helpful in charting the direction of subsequent drafts. Later versions have benefitted enormously from the insightful comments of Ainhoa Montoya, Čarna Brković, two anonymous reviewers, and my parents.

\section{References}

Aiyer, Ananthakrishnan. 2007. 'The Allure of the Transnational: Notes on Some Aspects of the Political Economy of Water in India,' Cultural Anthropology 22(4), $640-58$.

Althusser, Louis. 2008 [1971]. On Ideology. London: Verso.

American Anthropological Association. 1998. Code of Ethics of the American Anthropological Association. http://www.aaanet.org/committees/ethics/ethcode.html (accessed 28 March 2009).

Aronowitz, Stanley. 1992 [1973]. False Promises: The Shaping of American Working Class Consciousness. Durham, NC and London: Duke University Press.

Association of Social Anthropologists of the UK and the Commonwealth. 2011. Ethical Guidelines for Good Research Practice. http://www.theasa.org/ethics.shtml (accessed 8 June 2012). 
Babb, Florence E. 1999. “"Managua Is Nicaragua”: The Making of a Neoliberal City,' City \& Society 11(1-2), 27-48.

Bluestone, Barry and Bennett Harrison. 1982. The Deindustrialization of America: Plant Closings, Community Abandonment, and the Dismantling of Basic Industry. New York: Basic Books.

Bose, Purnima. 2010. 'General Electric, Corporate Personhood, and the Emergence of the Professional Manager,' in Purnima Bose and Laura E. Lyons (eds.). Cultural Critique and the Global Corporation, 28-63. Bloomington: Indiana University Press.

Bourgois, Philippe. 2011. 'Lumpen Abuse: The Human Cost of Righteous Neoliberalism,' City \& Society 23(1), 2-12.

Brown, Wendy. 2005. 'Neoliberalism and the End of Liberal Democracy,' in Edgework: Critical Essays on Knowledge and Politics, 37-59. Princeton: Princeton University Press.

Burden, Melissa. 2009. 'Genesee County and Flint Unemployment Rates Edge Up Slightly in July,' The Flint Journal.

http://www.mlive.com/business/midmichigan/index.ssf/2009/08/genesee_county_and_flint_unemp_1.html (accessed 4 October 2012).

Butler, Tim. 2003. 'Living in the Bubble: Gentrification and its 'Others' in North London,' Urban Studies 40(12), 2469-86.

Clemens, Paul. 2011. Punching Out: One Year in a Closing Auto Plant. New York: Anchor Books.

CNNMoney. 2009. The 10 Largest US Bankruptcies. http://money.cnn.com/galleries/2009/fortune/0905/gallery.largest_bankruptcies.fortune/ 4.html (accessed 18 April 2012). 
. 2012. 'General Motors,' Fortune 500: A Database of 50 Years of FORTUNE's List of America's Largest Corporations.

http://money.cnn.com/magazines/fortune/fortune500_archive/snapshots/2005/563.html (accessed 13 April 2012).

Collison, Robert and Sturla Gunnarsson. 1985. Final Offer. 78 min. 36 s.: National Film Board of Canada.

Comaroff, Jean and John L. Comaroff. 2001. Millenial Capitalism and the Culture of Neoliberalism. Durham, NC and London: Duke University Press.

Congressional Oversight Panel. 2010. 'The Unique Treatment of GMAC Under the TARP.' March Oversight Report, submitted under Section 125(b)(1) of Title 1 of the Emergency Economic Stabilization Act of 2008, Pub. L. No. 110-343.

Dandaneau, Steven P. 1996. A Town Abandoned: Flint, Michigan Confronts Deindustrialization. New York: SUNY Press.

Dobrzeniecki, Peter. 2006. City of Flint, Michigan: Comprehensive Annual Financial Report for the Fiscal Year Ended June 30, 2006. Flint: City of Flint/Donald J. Williamson, Mayor.

Duggan, Daniel. 2008. 'Flint Has Believers - With Cash.' Crain's Detroit Business. http://www.crainsdetroit.com/article/20081012/FREE/810130345 (accessed 30 April 2012).

Duménil, Gérard and Dominique Lévy. 2001. 'Costs and Benefits of Neoliberalism. A Class Analysis,' Review of International Political Economy 8(4), 578-607.

- 2004. Capital Resurgent: Roots of the Neoliberal Revolution. Cambridge, MA and London: Harvard University Press.

- 2005. 'The Neoliberal (Counter-)Revolution,' in Alfredo Saad-Filho and Deborah Johnston (eds.), Neoliberalism: A Critical Reader, 9-19. London: Pluto Press. 
Eisenberg, Richard and Debra Wishik Englander. 1987. 'The Best Places to Live in America.' Money.

http://money.cnn.com/magazines/moneymag/moneymag_archive/1987/08/01/83995/ (accessed 25 September 2012).

Fasenfest, David and James Jacobs. 2003. 'An Anatomy of Change and Transition: The Automobile Industry of Southeast Michigan,' Small Business Economics 21(2), 15372.

Federal Bureau of Investigation. 2010. 'Crimes Reported by Flint City Police Dept, Michigan.' Uniform Crime Reporting Statistics - UCR Data Online. Washington, DC: US Department of Justice.

Feldman, Judy. 1999. 'Buy a Home With No Cash Down.' Money Magazine. http://money.cnn.com/magazines/moneymag/moneymag_archive/1999/07/01/262285/i ndex.htm (accessed 16 April 2012).

Fine, Sidney. 1965. 'The General Motors Sit-Down Strike: A Re-Examination,' The American Historical Review 70(3), 691-713.

Flint Journal staff. 1999. 'Genesee Valley Becomes New 'Downtown' for Flint Area.' The Flint Journal. http://www.flintjournal.com/20thcentury/1970/1970main.html (accessed 25 April 2012).

Fonger, Ron. 2011. 'Into Survival Mode: With 1,500 Cut Off Welfare, Agencies and Families Prepare for Harder Times.' The Flint Journal.

http://www.mlive.com/news/flint/index.ssf/2011/10/survival_mode_with_1500_cut_of. html (accessed 3 October 2011).

—. 2012. 'Mixed Role: Some Believe UAW Helped GM Into and Out Of 2009 Financial Crash.' The Flint Journal.

http://www.mlive.com/news/flint/index.ssf/2012/02/gms_crash.html (accessed 13 April 
2012).

Friedman, Milton. 1962. Capitalism and Freedom. Chicago: Chicago University Press.

Friedman, Milton and Rose Friedman. 1990 [1979]. Free to Choose: A Personal Statement. Orlando: Mariner Books.

Gledhill, John. 2003. 'Neoliberalismo e ingobernabilidad: Caciquismo, militarización y movilización popular en el México de Zedillo,' Relaciones 24(96), 41-78.

- 2004. 'Neoliberalism,' in David Nugent and Joan Vincent (eds.). A Companion to the Anthropology of Politics, 332-48. Oxford: Blackwell.

Glick Schiller, Nina. 2011. 'Localized Neoliberalism, Multiculturalism and Global Religion: Exploring the Agency of Migrants and City Boosters,' Economy and Society 40(2), 211-38.

Goldman, David. 2009. 'There Goes Another \$30 Billion.' CNNMoney. http://money.cnn.com/2009/06/01/news/economy/gm_auto_bailout/index.htm (accessed 30 April 2012).

Goode, Judith and Jeff Maskovsky. 2001. The New Poverty Studies: The Ethnography of Power, Politics, and Impoverished People in the United States. New York: New York University Press.

Graham, David V. 1999. 'AutoWorld Flops.' The Flint Journal. http://www.flintjournal.com/20thcentury/1980/1980auto.html (accessed 25 April 2012).

Greenhouse, Carol. 2005. 'Hegemony and Hidden Transcripts: The Discursive Arts of Neoliberal Legitimisation,' American Anthropologist 107(3), 356-68.

Hairong, Yan. 2003. 'Neoliberal Governmentality and Neohumanism: Organizing Suzhi/Value Flow through Labor Recruitment Networks,' Cultural Anthropology 
$18(4), 493-523$.

Harrison, Graham. 2005. 'Economic Faith, Social Project and a Misreading of African Society: The Travails of Neoliberalism in Africa,' Third World Quarterly 26(8), 130320.

Harvey, David. 2005. A Brief History of Neoliberalism. New York: Oxford University Press.

- 2011. The Enigma of Capital and the Crises of Capitalism. Oxford: Oxford University Press.

Hayek, Friedrich. 2007 [1944]. The Road to Serfdom. Chicago: University of Chicago Press.

1978. Law, Legislation and Liberty, Volume 2: The Mirage of Social Justice. Chicago and London: University of Chicago Press.

Helper, Susan. 1991. 'Strategy and Irreversibility in Supplier Relations: The Case of the US Automobile Industry,' Business History Review 65(4), 781-824.

Highsmith, Andrew R. 2009. 'Demolition Means Progress: Urban Renewal, Local Politics, and State-Sanctioned Ghetto Formation in Flint, Michigan,' Journal of Urban History 35(3), 348-68.

Ingle, Larry. 1998. 'Living the Truth, Speaking to Power,' in Chuck Fager (ed.). The Best of Friends, Vol. 1. Fayetteville, NC: Kimo Press.

Isidore, Chris. 2008. 'Bush Announces Auto Rescue.' CNNMoney. http://money.cnn.com/2008/12/19/news/companies/auto_crisis/index.htm (accessed 18 April 2012).

2010. 'GM Buys Subprime Lender for \$3.5 Billion.' CNNMoney. 
http://money.cnn.com/2010/07/22/news/companies/gm_americredit/index.htm (accessed 18 April 2012).

Jessop, Bob. 2002. 'Liberalism, Neoliberalism, and Urban Governance: A StateTheoretical Perspective,' Antipode 34(3), 452-72.

Karan, Pradyumna Prasad and Kristin Eileen Stapleton (eds.). 1997. The Japanese City. Lexington, KY: The University Press of Kentucky.

Karjanen, David. 2010. 'Opposition to the Living Wage: Discourse, Rhetoric, and American Exceptionalism,' Anthropology of Work Review 31(1), 4-14.

Kemper, Alison and Roger L. Martin. 2010. 'After the Fall: The Global Financial Crisis as a Test of Corporate Social Responsibility Theories,' European Management Review 7(4), 229-39.

Kingfisher, Catherine and Jeff Maskovsky. 2008. 'Introduction: The Limits of Neoliberalism,' Critique of Anthropology 28(2), 115-26.

Kraus, Henry. 1985 [1947]. The Many and the Few: A Chronicle of the Dynamic Auto Workers. Urbana and Chicago: University of Illinois Press.

Lander, E. 2001. 'Los derechos de propiedad intelectual en la geopolítica del saber de la sociedad global,' Comentario Internacional: Revista del Centro Andino de Estudios Internacionales 2(2), 73-102.

Levin, Doron P. 1993. 'GM Lost \$23.5 Billion Last Year.' The New York Times. http://www.nytimes.com/1993/02/12/business/company-reports-gm-lost-23.5-billionlast-year.html (accessed 16 April 2012).

Lichtenstein, Nelson. 2000. 'Class Politics and the State During World War Two,' International Labor and Working-Class History 58 (October), 261-74.

Longley, Kristin. 2009. “"Boisterous, Supportive, Grateful:” Michael Moore Says Flint Audience for "Capitalism” was Incomparable to Others.' The Flint Journal. 
http://blog.mlive.com/flint-city-beat/2009/09/post.html (accessed 10 October 2012).

—. 2011. 'Emergency Manager Michael Brown Appointed to Lead Flint Through Second State Takeover.' The Flint Journal.

http://www.mlive.com/news/flint/index.ssf/2011/11/emergency_manager_michael_bro w.html (accessed 30 March 2012).

Lord, George F. and Albert C. Price. 1992. 'Growth Ideology in a Period of Decline: Deindustrialization and Restructuring, Flint Style,' Social Problems 39(2), 155-69.

Lynd, Staughton. 1979. 'Investment Decisions and the Quid Pro Quo Myth,' Case Western Law Review, 396-427.

Machniak, Christofer. 1999. 'Outcounty Population Skyrockets; City's Slips.' The Flint Journal. http://www.flintjournal.com/20thcentury/1960/1960pop.html (accessed 25 April 2012).

Marx, Karl. 1993 [1857]. 'Grundrisse: Foundations of the Critique of Political Economy.' Hammondsworth: Penguin.

Maskovsky, Jeff and Catherine Kingfisher. 2001. 'Introduction to Globalization, Neoliberalism and Poverty in Mexico and the United States,' Urban Anthropology and Studies of Cultural Systems and World Economic Development 30(2-3), 105-23.

May, Shannon. 2010. 'Rethinking Anonymity in Anthropology: A Question of Ethics,' Anthropology News 2010 (April), 10-3.

Miller, James M. 1999a. 'Crackdowns on “Reds," Booze Didn’t Silence Decade's Roar.' The Flint Journal.

http://www.flintjournal.com/20thcentury/1920/1920main.html (accessed 19 April 2012).

Miller, James M. 1999b. 'Litany of Troubles Left Flint's Foundations Cracked.' The Flint Journal. http://www.flintjournal.com/20thcentury/1980/1980main.html (accessed 
6 April 2012).

Molé, Noelle J. 2010. 'Precarious Subjects: Anticipating Neoliberalism in Northern Italy's Workplace,' American Anthropologist 112(1), 38-53.

Moore, Michael. 1989. Roger \& Me. 91 mins: Warner Bros. Inc.

-1992. Pets or Meat: The Return to Flint. 23 mins: Dog Eat Dog Films.

- 2009. Capitalism: A Love Story. 127 min.: Overture Films/Paramount Vantage/The Weinstein Company/Dog Eat Dog Films.

Morgen, Sandra. 2001. 'The Agency of Welfare Workers: Negotiating Devolution, Privatization, and the Meaning of Self-Sufficiency,' American Anthropologist 103(3), $747-61$.

Morgen, Sandra and Jeff Maskovsky. 2003. 'The Anthropology of Welfare "Reform": New Perspectives on US Urban Poverty in the Post-Welfare Era,' Annual Review of Anthropology 32, 315-38.

Mostafavi, Beata. 2008. 'Michigan Governor Jennifer Granholm Tours Downtown Flint's Renovation Effort, Calls It "Cool." Michigan Live.

http://blog.mlive.com/newsnow_impact/2008/07/gov_jennifer_granholm (accessed 14 July 2012).

Nash, June C. 1989. From Tank Town to High Tech: The Clash of Community and Industrial Cycles. Albany: State University of New York.

— 1995. 'Post-Industrialism, Post-Fordism, and the Crisis in World Capitalism,' in F. C. Gamst (ed.). Meanings of Work: Considerations for the 21st Century, 189-211. Albany: SUNY Press.

Newman, Christy E., Maria Bonar, Heath S. Greville, Sandra C. Thompson, Dawn Bessarab and Susan C. Kippax. 2007. "“Everything Is Okay:" The Influence of Neoliberal Discourse on the Reported Experiences of Aboriginal People in Western 
Australia Who Are HIV-Positive,' Culture, Health \& Sexuality 9(6), 571-84.

NYSE. 2012. Historische Kurse - General Motors Company (GM).

http://de.finance.yahoo.com/q/hp?s=GM\&a=00\&b=2\&c=1962\&d=03\&e=11\&f=2012

$\underline{\mathrm{g}}=\mathrm{m} \& \mathrm{z}=66 \& \mathrm{y}=528($ accessed 12 April).

Ong, Aihwa. 2006. Neoliberalism as Exception: Mutations in Citizenship and Sovereignty. London: Duke University Press.

Peck, Jamie and Adam Tickell. 2002. 'Neoliberalizing Space,' Antipode 34(3), 380404.

Read, Jason. 2009. 'A Genealogy of Homo-Economicus: Neoliberalism and the Production of Subjectivity,' Foucault Studies 6 (February), 25-36.

Regassa, Hailu and Ahmad Ahmadian. 2007. 'Comparative Study of American and Japanese Auto Industry: General Motors Versus Toyota Motors Corporations,' The Business Review, Cambridge 8(1), 1-11.

Richardson, Pete. 2007. 'Two-Tier Kin: Imagining and Contesting Familism in a UAW Local,' Journal of Anthropological Research 63(1), 73-93.

Saad Filho, Alfredo and Deborah Johnston. 2005. Neoliberalism: A Critical Reader. London: Pluto Press.

Sauter, Michael B., Douglas A. McIntyre, Ashley C. Allen and Alexander E.M. Hess. 2012. 'The Most Dangerous Cities in America.' NBC News.

http://www.nbcnews.com/business/most-dangerous-cities-america-832351 (accessed 12 February 2013).

Schumpeter, Joseph. 1976 [1942]. Capitalism, Socialism and Democracy. New York: Harper \& Row.

Schwegler, Tara A. 2008. 'Take It from the Top (Down)? Rethinking Neoliberalism and Political Hierarchy in Mexico,' American Ethnologist 35(4), 682-700. 
Sherman, M. 2009. A Short History of Financial Deregulation in the United States. Washington, DC: Center for Economic and Policy Research.

Shore, Cris and Susan Wright. 1999. 'Audit Culture and Anthropology: Neo-Liberalism in British Higher Education,' The Journal of the Royal Anthropological Institute 5(4), $557-75$.

Society of Professional Journalists. 1996. Code of Ethics. http://www.spj.org/ethicscode.asp (accessed 3 May 2013).

Taylor, Alex, Jung Ah Pak and Rosalind Klein Berlin. 1990. 'The New Drive to Revive GM.' FORTUNE Magazine.

http://money.cnn.com/magazines/fortune/fortune_archive/1990/04/09/73367/index.htm (accessed 16 April 2012).

Tressell, Robert. 1914 [2012]. The Ragged Trousered Philanthropists. London: Wordsworth.

US Bureau of Labor Statistics. 2009a. Hourly Compensation Costs for All Employees in US Dollars: Mexico. ftp://ftp.bls.gov/pub/special.requests/foreignlabor/aemexico.txt (accessed 30 May 2012).

2009b. Hourly Compensation Costs for All Employees in US Dollars: United States.

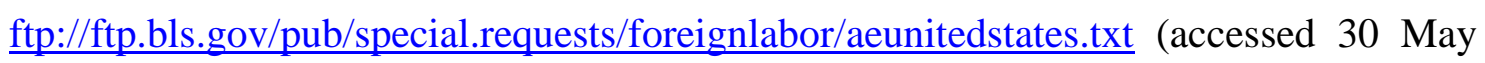
2012).

—. 2012a. 'Data Series SAU2626403000011: Employees in Manufacturing, Flint, Michigan, 1958-2002, Not Seasonally Adjusted.' State and Area Employment, Hours, and Earnings (SIC). http://data.bls.gov/pdq/querytool.jsp?survey=sa (accessed 21 May 2012).

2012b. 'Data Series SMU26224203000000001: Employees in Manufacturing, 
Flint, Michigan, 1990-2011, Not Seasonally Adjusted.' State and Area Employment, Hours, and Earnings (NAICS). http://data.bls.gov/pdq/querytool.jsp?survey=sm (accessed 21 May 2012).

—. 2012c. 'Data Series SMU26224204200000001: Employees in Retail Trade, Flint, Michigan, 1990-2011, Not Seasonally Adjusted.' State and Area Employment, Hours, and Earnings (NAICS). http://data.bls.gov/pdq/querytool.jsp?survey=sm (accessed 21 May 2012).

US Census Bureau. 2000. '48502 ZIP Code'. Table P001: Census 2000 Summary File. http://factfinder2.census.gov (accessed 30 April 2012).

- 2010a. DP-1: Profile of General Population and Housing Characteristics, Demographic Profile Data. http://factfinder2.census.gov (accessed 23 March 2012).

- 2010b. DP-03: Selected Economic Characteristics, 2006-2010 American Community Survey 5-Year Estimates. http://factfinder2.census.gov (accessed 23 March 2012).

- 2010c. 'DP-03: Selected Economic Characteristics: Flint, Michigan.' 2010 American Community Survey 1-Year Estimates. http://factfinder2.census.gov (accessed 23 August 2012).

- 2010d. 'S1701 - Poverty Status in the Past 12 Months: Flint, Michigan.' 2010 American Community Survey 1-year estimates. http://facfinder2.census.gov (accessed 16 March 2012).

—. 2010e. 'Table B01003: Total Population, Flint Michigan.' 2010 American Community Survey. Washington, DC: US Department of Commerce.

Wacquant, Loïc. 2012. 'Three Steps to a Historical Anthropology of Actually Existing Neoliberalism,' Social Anthropology 20(1), 66-79. 
2009. Punishing the Poor: The Neoliberal Government of Social Insecurity. London: Duke University Press.

Walling, Dayne. 2012. 'Change Tax Code to Feed Starving Michigan Cities.' Bridge News and Analysis. The Center for Michigan.

http://bridgemi.com/2012/05/guest-column-change-tax-code-to-feed-starvingmichigan-cities/\#.T6shQRx6_Eb (accessed 10 May 2013).

Williams, Monci Jo, Rosalind Klein Berlin and Ann Goodman. 1986. 'Rushing Into the Mortgage Game.' FORTUNE Magazine.

http://money.cnn.com/magazines/fortune/fortune_archive/1986/04/28/67468/index.htm (accessed 15 April 2012).

Worth-Nelson, Jan. 2013. 'Village Life: You Better Get This Right, Uptown Dudes.' East Village Magazine. http://www.eastvillagemagazine.org/en/features14/19252village-life-you-better-get-this-right-uptown-dudes (accessed 15 April 2013).

Wright, Erik Olin. 2000. 'Working-Class Power, Capitalist-Class Interests, and Class Compromise,' American Journal of Sociology 105(4), 957-1002.

Yousuf, Hibah. 2009. 'GMAC Receives 3rd Round of Bailout Funds.' CNNMoney. http://money.cnn.com/2009/12/30/news/companies/gmac_bailout/index.htm (accessed 16 April 2012).

Zwerdling, Daniel. 1982. 'And Then There's The Disneyland Solution,' The Progressive 1982 (July), 34-5. 